УдК 331:658.3

O. В. Балуєва,

д. е.н., професор, проректор з наукової роботи, Аонеиький державний університет управління

ORCID ID: 0000-0003-3091-3137

Г. В. Снопенко,

аспірант, Аонеиький державний університет управління

ORCID ID: 0000-0002-5736-3609

DOI: $10.32702 / 2306-6814.2021 .21 .30$

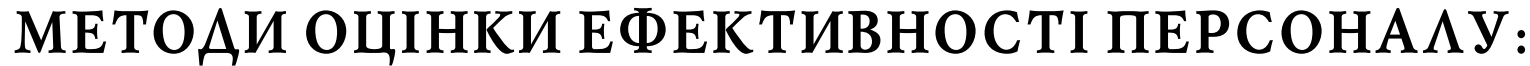 ЕВО ЮЮЦІЯ ПІА ВПАИВОМ РОЗВИТКУ ТЕХНО ОГІЙ
}

\author{
O. Balueva, \\ Doctor of Economic Sciences, Professor, Vice-Rector for Research, Donetsk State University of Management \\ H. Snopenko, \\ Postgraduate student, Donetsk State University of Management
}

\section{PERSONNEL PERFORMANCE APPRAISAL METHODS: EVOLUTION UNDER THE INFLUENCE} OF TECHNOLOGICAL DEVELOPMENTS

Під впливом зовнішніх факторів і розвитку технологій штучного інтелекту змінюються корпоративні стратегії роботи з людськими ресурсами, і одним з головних завдань HR-підрозділу стає регулярна оцінка персоналу. Завдяки розвитку цифрових інструментів у сфері оцінки персоналу сучасним роботодавцям відкриваються нові можливості скорочення тимчасових та фінансових витрат на забезпечення бізнесу людськими ресурсами. В статті розглянуто сучасні тренди, які суттєво впливають на менеджмент персоналу і трансформують HR-функцію на підприємствах. Визначено найбільш популярні методи оцінки персоналу в сучасних організаціях, а також проаналізовано їхні переваги та недоліки. Досліджено найзначніші технологічні розробки останніх років, які мають перевагу над класичними інструментами оцінки в умовах переходу персоналу на віддалений режим роботи та розгалуженості виробничих команд.

External factors and advances in artificial intelligence technology are changing corporate human resource strategies, and one of the main tasks of the HR department nowadays is regular staff appraisal. There is a natural integration of assessment tools and data in companies' activities, ensuring consistency and validity of different $H R$ decisions at all stages of the employee lifecycle. $A$ well-organised employee appraisal process is an objective and reliable source of information that is valuable to both employees and managers. Due to the development of the digital tool in the field of personnel assessment, today's employers have new opportunities for reducing the time and financial costs of providing human resources for the business.

The article describes current trends that significantly impact personnel management and are transforming the companies' HR functions. The most popular personnel assessment methods in modern organisations have been identified, and their advantages and disadvantages have been analysed. Traditional methods emphasize rating the individual's personality traits, such as initiative, dependability, drive, creativity, integrity, intelligence, leadership potential, etc. On the other hand, modern methods are more inclined towards job achievement and evaluation of work results. Modern methods best suit the organizations faced with pacing and rely on performance, results, and employee productivity.

In addition, the most significant technological developments in recent years, which have been the benefit of classical assessment tools in the transition of personnel to a remote mode of operation and branched production teams, have been identified. Moreover, it has been substantiated that the traditional goal-setting and annual performance appraisal system focuses on past performance rather than current and future employee performance. Therefore, the importance of appraisal and feedback to employees is reduced, which prevents them from working on their behaviour while performing 
their routine tasks. In this regard, companies are encouraged to switch to a continuous process of goal setting, evaluation and feedback in personnel performance management, and HR managers are encouraged to use E. Jacks' theory of personnel assessment, given that each manager or employee's abilities must be appropriate for the position.

КлючоВі слоЪа: оцінка персоналу, методи оцінки персоналу, HR-аналітика, технології оцінки персоналу, зВоротний зВ'язок, аВтоматизація HR-функції, штучний інтелект.

Key words: personnel evaluation, personnel evaluation methods, HR-analytics, personnel evaluation technologies, feedback, automation of HR function, artificial intelligence.

\section{ПОСТАНОВКА ПРОБАЕМИ}

Низькі показники продуктивності праці в Україні [1, c. 11] безпосередньо впливають на рівень конкурентоспроможності вироблених товарів і послуг на внутрішньому і зовнішньому ринках, що в підсумку відбивається на економіці країни і на рівні життя і добробуту громадян. Однією з актуальних і досить гострих проблем як компаній бізнес-сегменту, так і державних органів управління $\epsilon$ підвищення ефрективності діяльності офрісних співробітників, рішення якої неможливе без сучасних інструментів моніторингу ефективності повсякденної діяльності персоналу. Дистанційна робота посилила потребу менеджменту в застосуванні data driven-підходу i автоматизації для підвищення продуктивності праці та операційної ефективності українських компаній, тому питання оцінки ефективної робочої поведінки персоналу актуальні і потребують більш детального розгляду.

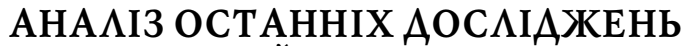 І ПУБАІКАЦІЙ}

Останнє десятиріччя відзначається інтенсивним зростанням інтересу науки та практики до проблем управління персоналом. Значним внеском у дослідження методів оцінювання персоналу стали праці зарубіжних і вітчизняних вчених, зокрема О.В. Крушельницької [2], С.О. Цимбалюк, О.М. Білик [3], В.В. Малтиз [4], А.Я. Кібанова [5], С.Н. Апенько [6], між тим, проблема пошуку оптимальних методів та інструментів оцінки, релевантних сучасним умовам ведення бізнесу, досі не вирішена і потребує більш детального дослідження.

\section{META CTATTI}

Метою статті $\epsilon$ дослідження розвитку технологій оцінки персоналу підприємств під впливом пандемії та розвитку штучного інтелекту.

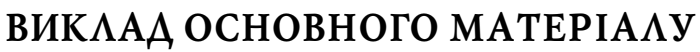

Безумовно, стратегічно важливою складовою будьякого бізнесу є персонал. Доведено, що компанії з квалі- фікованими кадрами мають більший потенціал для свого розвитку і серйозну конкурентну перевагу на ринку. В 20-30-х роках минулого століття виник інтерес до наукового підходу в організації праці та контролю працівників, у 50-80-х роках почали з'являтися схеми для тестування різних категорій співробітників, спрямовані на виявлення результативності їх роботи. За радянських часів атестація та інтерв'ю були єдиними інструментами оцінки співробітників. Очевидно, що для масштабної, об'єктивної та ефекттивної аналітики цього було не достатньо, і з початку 90-х відбувається систематизація наявних знань і розвиток нових технологій. Так, перше місце в рейтингу HR-інструментів зайняли психологічні тести, на зміну їм прийшли ситуаційно-поведінкові тести, які дозволяють оцінити реальні дії працівника в змодельованій ситуації, згодом до них додали оцінне інтерв'ю івесь цей комплекс перетворився в "центр оцінки".

На сучасний ринок зайнятості в 2020-2021рp. вплинула пандемія коронавірусу і ії̈ наслідок - чергова економічна і соціальна криза. У зв'язку з цим на ринку праці спостерігаються наступні тренди:

- прискорення автоматизації бізнесу і діджиталізація робочих місць;

- збільшення частки віддалених працівників;

— поява формату гібридного офрісу;

- зростання попиту на фрахівців в цифровому сегменті, у сорері інформаційної безпеки;

- брак молодих фахівців в продажах і на виробництві;

- активний розвиток сфери гейм-дизайну;

- посилення уваги до корпоративної культури;

- застосування маркетингових інструментів в HR;

- використання штучного інтелекту в управлінні персоналом (поява високотехнологічних продуктів, здатних вимірювати рівень стресу, залученість і ефективність співробітників у режимі реального часу) [7].

Вищезазначені тренди трансформують HR-фуннцію, фокусуючи її на необхідності автоматизації процесів управління на кожному кроці життєвого циклу співробіт-

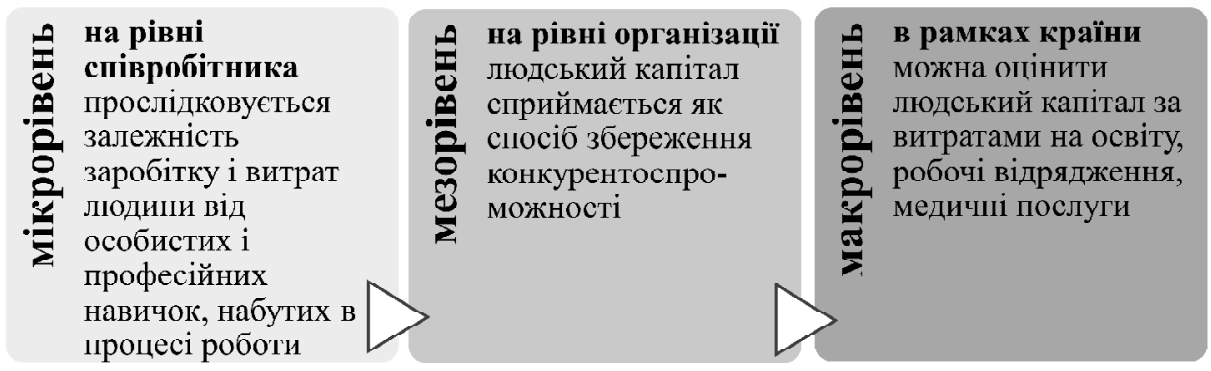

Рис. 1. Рівні для оцінки людського капіталу 
Таблиця 1. Методи оцінки персоналу: переваги і обмеження

\begin{tabular}{|c|c|c|c|}
\hline Метод оцінки & Характеристика & Переваги & Обмеження \\
\hline Атестація & $\begin{array}{l}\text { Перевірка співробітника на } \\
\text { відповідність займаній посаді }\end{array}$ & $\begin{array}{l}\text { - Організовується на регулярній основі; } \\
\text { - дозволяє оцінити потенціал кожного } \\
\text { співробітника }\end{array}$ & $\begin{array}{l}\text { - Є ризик задати загальні критерії та } \\
\text { отримати загальні результати; } \\
\text { - відсутність зворотного зв'язку від } \\
\text { співробітників; } \\
\text { - тривалий; } \\
\text { - трудомісткий; } \\
\text { - дорогий }\end{array}$ \\
\hline $\begin{array}{l}\text { Центр оцінки } \\
\text { (assessment centre) }\end{array}$ & $\begin{array}{l}\text { Оцінка поведінки } \\
\text { співробітника в змодельованих } \\
\text { ситуаціях }\end{array}$ & $\begin{array}{l}\text { - Комплексний; } \\
\text { - найточніше оцінює компетенції; } \\
\text { - конфіденційний; } \\
\text { - індивідуальний підхід; } \\
\text { - універсальний в застосуванні }\end{array}$ & $\begin{array}{l}\text { - Важко провести онлайн; } \\
\text { - немає зворотного зв'язку від } \\
\text { співробітників; } \\
\text { - тривалий; } \\
\text { - трудомісткий; } \\
\text { - дорогий }\end{array}$ \\
\hline Оцінка 360 & $\begin{array}{l}\text { Опитування робочого } \\
\text { оточення співробітника: колег, } \\
\text { безпосереднього керівника, } \\
\text { підлеглих, іноді клієнтів }\end{array}$ & $\begin{array}{l}\text { - Більш об'єктивний результат за рахунок } \\
\text { широкого кола оцінюючих; } \\
\text { - різнобічна оцінка; } \\
\text { - живий зворотний зв'язок; } \\
\text { - зміцнення корпоративної ідентичності; } \\
\text { - виявлення проблем, про які керівництво } \\
\text { може не знати, але знають співробітники }\end{array}$ & $\begin{array}{l}\text {-Суб'єктивний: основа оцінки - } \\
\text { думка співробітників; } \\
\text { - слабо підходить для кадрових } \\
\text { рішень-вимагає доповнення іншими } \\
\text { дослідженнями; } \\
\text { - трудомісткий; } \\
\text { - не можна проводити часто }\end{array}$ \\
\hline Тестування & $\begin{array}{l}\text { Оцінка співробітників за } \\
\text { допомогою тестів у } \\
\text { паперовому або віртуальному } \\
\text { форматі }\end{array}$ & $\begin{array}{l}\text { - Недорогий; } \\
\text { - зручний; } \\
\text { - підходить для експрес-оцінок; } \\
\text { - підходить для малого бізнесу; } \\
\text { - не вимагає спеціальних психологічних } \\
\text { компетенцій HR-менеджера }\end{array}$ & $\begin{array}{l}\text { - С ризик задати загальні критерії та } \\
\text { отримати загальні результати; } \\
\text { - немає зворотного зв'язку від } \\
\text { співробітників; } \\
\text { - тривалий; } \\
\text { - трудомісткий }\end{array}$ \\
\hline $\begin{array}{l}\text { Управління по } \\
\text { цілям } \\
\text { (Management by } \\
\text { Objectives) }\end{array}$ & $\begin{array}{l}\text { Робота фахівців } \\
\text { підпорядкована цілям } \\
\text { організації і пов'язана } 3 \text { ними }\end{array}$ & $\begin{array}{l}\text { - Підвищує мотивацію: співробітники } \\
\text { бачать взаємозв'язок своєї роботи і цілей } \\
\text { компанії; } \\
\text {-є елемент зворотного зв'язку; } \\
\text { - підвищує ефективність контролю і } \\
\text { планування }\end{array}$ & $\begin{array}{l}\text { - Суб'єктивний; } \\
\text { - орієнтований на минулі досягнення; } \\
\text { - вимагає великих витрат часу; } \\
\text { - збільшує обсяг роботи } 3 \\
\text { документами; } \\
\text { - складно встановлювати } \\
\text { верифіковані цілі }\end{array}$ \\
\hline $\begin{array}{l}\text { Управління } \\
\text { результативністю } \\
\text { (Performance } \\
\text { Management) }\end{array}$ & $\begin{array}{l}\text { Керівник ставить завдання } \\
\text { разом зі співробітником; } \\
\text { спільна перевірка результату } \\
\text { здійснюється } \\
\text { після звітного періоду }\end{array}$ & $\begin{array}{l}\text { - Приділяє увагу результату, процесу і засобам, } \\
\text { які були витрачені на досягнення мети; } \\
\text { - оцінює професійні та особистісні якості } \\
\text { кожного члена колективу; } \\
\text { - транслює корпоративну культуру через } \\
\text { компетенції; } \\
\text { - націлений на довгострокове навчання і } \\
\text { розвиток персоналу }\end{array}$ & $\begin{array}{l}\text { - Вимагає великих затрат часу; } \\
\text { - можливий тільки в організації з } \\
\text { розвиненою корпоративною } \\
\text { культурою; } \\
\text { - трудомісткий; } \\
\text { - вимагає підготовки HR-відділу, } \\
\text { лінійних менеджерів і керівників }\end{array}$ \\
\hline $\begin{array}{l}\text { Метод експертних } \\
\text { оцінок }\end{array}$ & $\begin{array}{l}\text { Оцінка проводиться групою } \\
\text { обраних роботодавцем } \\
\text { експертів, які спочатку } \\
\text { оцінюють працівника анонімно, } \\
\text { а потім обговорюють отримані } \\
\text { результати і приходять до } \\
\text { загального підсумку }\end{array}$ & $\begin{array}{l}\text { - Порівняно нетрудомісткий; } \\
\text { - дає швидкі результати }\end{array}$ & $\begin{array}{l}\text { - Буває неточний через суб'єктивні } \\
\text { оцінки; } \\
\text { - складність в доборі експертів }\end{array}$ \\
\hline Метод КРI & $\begin{array}{l}\text { Оцінка співробітника за } \\
\text { ключовими показниками } \\
\text { ефективності, які прив'язані до } \\
\text { цілей організації }\end{array}$ & $\begin{array}{l}\text { - Дає співробітникам чітке розуміння цілей } \\
\text { і критеріїв оцінки їх роботи; } \\
\text { - об'єкт оцінки - не тільки діяльність } \\
\text { співробітника, але і процеси компанії; } \\
\text { - допомагає коригувати план і розуміти, } \\
\text { чому не виконуються прогнозні показники }\end{array}$ & $\begin{array}{l}\text { - Підходить тільки для тих видів } \\
\text { діяльності, які піддаються } \\
\text { вимірюванню; } \\
\text { - є ризики неадекватних показників } \\
\text { і некоректних шкал; } \\
\text { - не враховує фактори, що впливають } \\
\text { на ефективність персоналу }\end{array}$ \\
\hline $\begin{array}{l}\text { Матричний метод } \\
\text { вимірювання } \\
\text { результативності }\end{array}$ & $\begin{array}{l}\text { Для кожної посади створюють } \\
\text { матрицю необхідних у роботі } \\
\text { ділових і особистісних } \\
\text { якостей, надалі матриця } \\
\text { порівнюється з компетенціями } \\
\text { конкретного співробітника }\end{array}$ & $\begin{array}{l}\text { - Допомагає інтегрувати корпоративні } \\
\text { цінності, професійні вимоги і особистісні } \\
\text { особливості співробітників; } \\
\text { - незначні витрати; } \\
\text { - можна проводити щоквартально; } \\
\text { - допомагає мотивувати людей і націлити } \\
\text { на досягнення цілей }\end{array}$ & $\begin{array}{l}\text { - Не можна проводити часто; } \\
\text { - можливості аналізу обмежені; } \\
\text { - об'єктивність і точність результату } \\
\text { обмежена }\end{array}$ \\
\hline $\begin{array}{l}\text { Метод } \\
\text { стандартних } \\
\text { оцінок }\end{array}$ & $\begin{array}{l}\text { Оцінка окремих аспектів } \\
\text { роботи співробітника } \\
\text { протягом обраного періоду за } \\
\text { стандартною шкалою, } \\
\text { результати оформляються у } \\
\text { вигляді оцінного листа }\end{array}$ & $\begin{array}{l}\text { - Незначні витрати; } \\
\text { - доступний; } \\
\text { - не вимагає спеціальної підготовки; } \\
\text { - не вимагає значних витрат часу; } \\
\text { - допомагає оцінювати співробітників } \\
\text { єдиним чином }\end{array}$ & $\begin{array}{l}\text { - Суб'єктивний; } \\
\text { - одностороння оцінка; } \\
\text { - на результатах можуть } \\
\text { позначитися особисті взаємини } \\
\text { співробітника і керівника; } \\
\text { - стандартна шкала не враховує } \\
\text { індивідуальних особливостей }\end{array}$ \\
\hline $\begin{array}{l}\text { Метод } \\
\text { ранжирування }\end{array}$ & $\begin{array}{l}\text { Розподіл співробітників за } \\
\text { рангами від кращого до } \\
\text { гіршого; результати } \\
\text { оформлюються в таблицю або } \\
\text { у вигляді діаграми }\end{array}$ & $\begin{array}{l}\text { - Простий; } \\
\text { - доступний; } \\
\text { - допомагає простежити за діяльністю } \\
\text { співробітників і порівняти отримані } \\
\text { результати з попередніми; } \\
\text { - дає інформацію для прийняття рішень по } \\
\text { персоналу: скорочення штату, } \\
\text { преміювання, підвищення заробітних плат }\end{array}$ & $\begin{array}{l}\text { - Суб'єктивний; } \\
\text { - може провокувати конфлікти; } \\
\text { - не можна порівняти групи } \\
\text { співробітників з різним } \\
\text { функціоналом; } \\
\text { - не інформативний на великих } \\
\text { групах співробітників }\end{array}$ \\
\hline
\end{tabular}


EKOHОМIЧНА НАУКА

ника і прискоренні впровадження нових технологій і платформ. Забезпечення більш комфортних умов роботи, сприяння розвитку професійних навичок фахівців, мотивування їх на досягнення нових цілей в рамках компанії - сучасні завдання HR-менеджера, які сьогодні виходять на перший план, оскільки від цього безпосередньо залежить конкурентоспроможність, репутація HRбренду і прибуток компанії.

Застосування сучасних HR-технологій, однозначно, позитивно впливає на ключовий актив компанії (людський капітал) [8, с. 96-98], але, щоб побудувати ефективну систему управління персоналом, потрібно володіти великим обсягом інформації про сам об'єкт управління-людський капітал.

У бізнесі під людським капіталом мається на увазі надійний економічний ресурс, ефективність якого залежить від постійної мотивації та розвитку в реаліях компанії. При цьому аналізувати людський капітал можна за різними ознаками, наприклад, за рівнем охоплення - в масштабах країни, міста або регіону, на рівні підприємства, на якому працює людина, або на рівні самого працівника (рис. 1).

Так, на рівні країни (макрорівень) можна оцінити людський капітал за витратами на освіту, робочі відрядження, медичні послуги. На рівні організації (мезорівень) людський капітал сприймається як спосіб збереження конкурентоспроможності підприємства. На рівні співробітника (мікрорівень) видна залежність заробітку і витрат людини від особистих і професійних навичок, набутих у процесі роботи. Однак при діловій оцінці співробітника найбільш поширеними є три види показників: оцінка особистих якостей працівника, оцінка результатів праці та оцінка процесів. За регулярністю ділової оцінки виділяють такі рівні: поточна оцінка, періодична оцінка та оцінка потенціалу співробітника [9].

У науковій літературі існує чимало класифрікацій методів оцінки персоналу. Методи оцінювання можна визначити за суб'єктом оцінювання як: індивідуальні, колективні, експертні та самооцінювання [10, с. 82].

Оцінка ділових якостей співробітників підприємства складне завдання, і для ії̈ вирішення необхідно обрати правильні інструменти. В таблиці 1 авторами визначено найбільш популярні методи оцінки персоналу в сучасних організаціях, а також проаналізовано їх переваги та недоліки.

Ефективність конкретного інструменту можна оцінити за двома основними показниками: точність і витрати на проведення оцінки. Найбільш точні інструменти - аналіз досвіду і досягнень людини, збір і перевірка рекомендацій, глибока індивідуальна оцінка. Невипадково спеціалісти з підбору персоналу в більшості випадків використовують саме ці методи для підбору кандидатів на відповідальні позиції. Однак ці інструменти дорогі, трудомісткі, їх застосування має обмежений характер. Якщо потрібно оцінити сотні, тисячі, а іноді десятки тисяч людей, точність повинна бути прийнятною, і важливо вкластися в стислі терміни і бюджет, у такому випадку цифровим інструментам оцінки немає альтернативи. До них відносяться тести (табл. 2), придатні для цілей оцінки та відбору, а також нові методи, засновані на використанні штучного інтелекту.

\section{Таблиця 2. Інструменти оцінки потенціалу} співробітника

\begin{tabular}{|c|c|}
\hline $\begin{array}{l}\text { Інструменти } \\
\text { оцінки } \\
\text { потенціалу } \\
\text { півробітника }\end{array}$ & Переваги \\
\hline ст Амтхауера & $\begin{array}{l}\text { Оцінює розумові здібності людини, виявляє здібності } \\
\text { до логіки, аналізу, синтезу, абстрагування }\end{array}$ \\
\hline ст Гілфорда & $\begin{array}{l}\text { Вимірює соціальний інтелект і здібності працівника до } \\
\text { психоаналізу }\end{array}$ \\
\hline ст Равена & $\begin{array}{l}\text { Виявляє здатності співробітника до постійної роботи } \\
\text { над собою і навчання }\end{array}$ \\
\hline $\begin{array}{l}\text { Іитувальник } \\
\text { ттела }\end{array}$ & $\begin{array}{l}\text { Визначає загальний рівень інтелекту, ступінь розвитку } \\
\text { уяви, емоційну стійкість, сприйнятливість до нового } \\
\text { радикалізму, наявність внутрішніх напружень }\end{array}$ \\
\hline $\begin{array}{l}\text { гитувальник } \\
\text { ефансона }\end{array}$ & $\begin{array}{l}\text { Відображає уявлення співробітника про себе як про } \\
\text { індивідуальність }\end{array}$ \\
\hline $\begin{array}{l}\text { льс-опитування } \\
0 \text { Yva.ai }\end{array}$ & Визначають лідерський потенціал співробітника \\
\hline тест & Визначає інтелектуальний рівень співробітника \\
\hline тест & Досліджує рівень емоційного інтелекту співробітника \\
\hline офесійні тести & Оцінюють професійні компетенції співробітника \\
\hline
\end{tabular}

Доцільно відмітити, що іноземних HR-срахівців вже давно не влаштовує підхід "Високий потенціал = значні результати + розвинені компетенції". Так, аналітик компанії "Bersin" Кім Ламру (Kim Lamoureux) вважає, що поняття "високопотенційний співробітник" стало втрачати свою цінність, оскільки компанії втратили розуміння самого потенціалу. І таким чином постає проблема: розширення пулу талантів компанії не додає стійкості компанії в майбутньому. Причина полягає в тому, що в нього потрапляють ті співробітники, які ефективні на своїх посадах, але вони не володіють потенціалом для роботи на більш високих позиціях [11].

Конкретизуємо, що потенціал - це прогноз майбутньої ефективності співробітника, наприклад, при підвищенні або ротації, який визначається здатністю співробітника самостійно вирішувати проблеми і завдання певного масштабу і бажанням нарощувати поточний рівень своїх завдань [12, с. 156].

Важливо враховувати, що оцінка потенціалу не вимагає аналізу всіх цілей і досягнень людини. Завдання керівника - знайти "пікові досягнення", найбільш масштабні і довгострокові проєкти або завдання, з якими успішно впорався співробітник, щоб відповісти на ключове питання, сорормульоване канадським вченим Елліоттом Джексом [13]: якого рівня завдання можна доручити цьому співробітнику з упевненістю в тому, що він впорається - за умови, що у нього будуть потрібні для цього знання і мотивація.

За теорією Джекса [5], здібності кожного керівника або співробітника повинні відповідати займаній посаді.

Здібності $=\mathrm{C} 1$ * $\mathrm{C} 2$ * C3 * C4 (рис. 2),

де: C1 (Complexity of information processing) - масштаб мислення - це розумовий потенціал співробітника, часовий горизонт завдань і рівень їх складності, який він здатний вирішити. Часовий горизонт - це здатність людини планувати на певну часову перспективу, ставити завдання і приймати рішення відповідно до складеного плану.

C2 (Competencies) - компетенції: профресійні компетенції, компетенції управлінця, загальні компетенції.

C3 (Commitment) - прихильність: бажання розвиватись в конкретній компанії і дотримуватись її норм і правил, бажання виконувати роботу конкретного типу. 


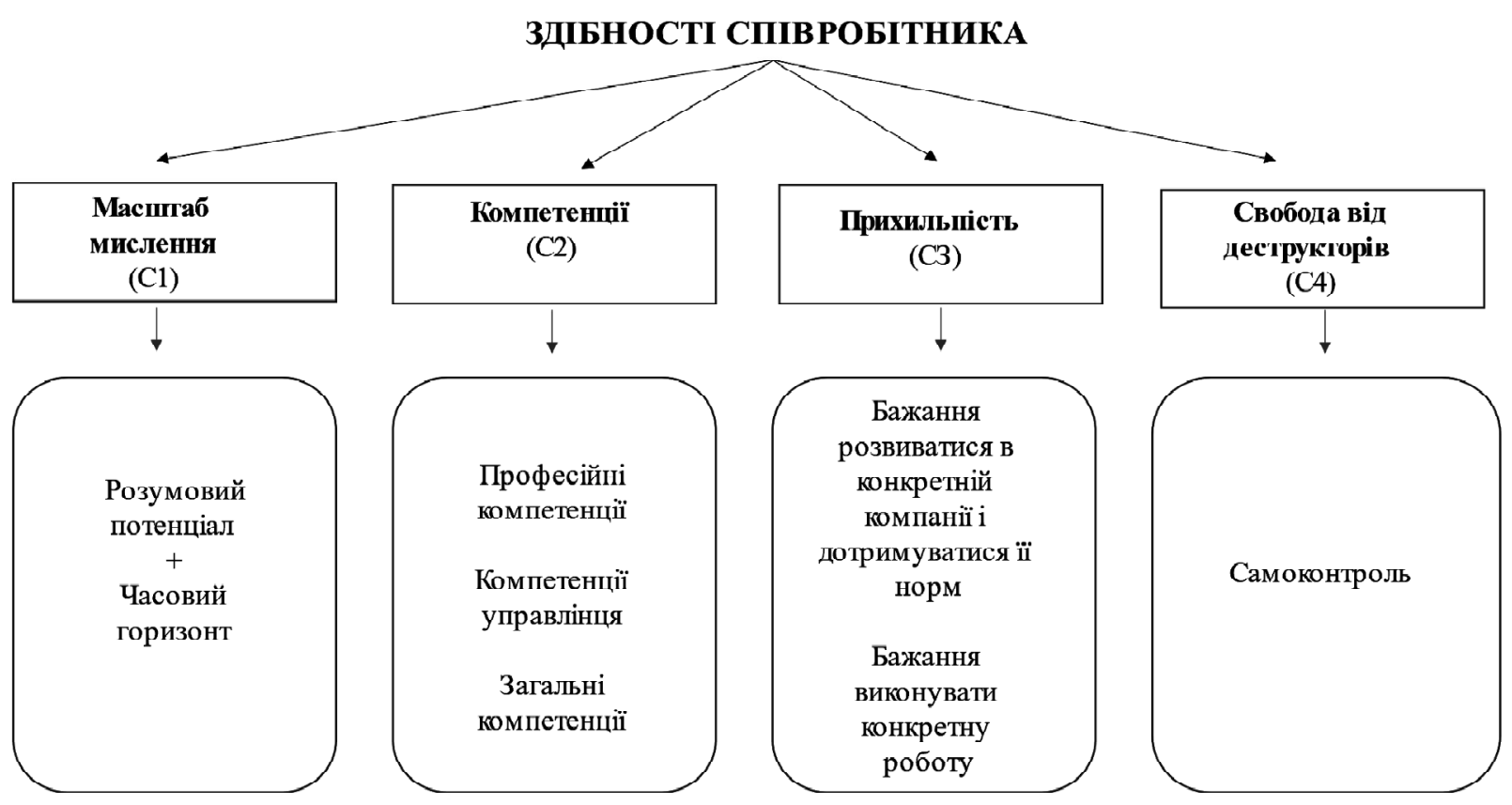

Рис. 2. Складові здібностей співробітника за теорією Е. Джекса

Джерело: [13].

C4 (Controlling self) - свобода від деструкторів: здатність контролювати себе і нести відповідальність за свої рішення.

Зазначимо, що найбільш критичним фрактором відповідності (який важко розвинути) є С1 - масштаб мислення.

Поряд з цим, автори згодні з твердженням вченого, що звичайні фрактори прийняття кадрових рішень - знання, досвід, мотивація, поведінкові компетенції - мають підлегле значення, саме тому цінність інтерв'ю, тестів здібностей і центрів оцінки всього $20 \%-60 \%$. Головним же в оцінці профрпридатності співробітників повинні стати здатність приймати рішення і планувати дії для досягнення мети в ситуації невизначеності. Цей критерій дещо спрощено можна назвати "прозорливістю". Щоб виміряти рівень прозорливості застосовують особливе інтерв'ю: людину залучають в спонтанне обговорення значимої для неї складної теми, а розшифровка бесіди виявляє способи фрормування суджень і аргументації.

Отже, традиційні кількісні, якісні і комбіновані методи актуальні і використовуються на практиці в багатьох компаніях, але в умовах сьогодення сформувалися інші глобальні тренди щодо підвищення ефективності оцінки персоналу за допомогою технологій штучного інтелекту (далі-Шا). Рішення в області Ш перетворюють масив розрізнених даних в структуровану інформацію, яка стає основою для прийняття стратегічних рішень і розвитку бізнесу.

Слід приділити увагу найзначнішим технологічним розробкам останніх років, які, на наш погляд, мають перевагу перед класичними інструментами оцінки в умовах переходу персоналу на віддалений режим роботи та розгалуженості виробничих команд.

Так, наприклад, рішення EmployeeXМвід QualtricsXM [14] дозволяє безперервно збирати зворотній зв'язок від кожного співробітника за допомогою опитувань і експрес-тестів і використовувати цю інфрормацію для підвищення залученості, збільшення ефрективності праці та впровадження інновацій, враховуючи інтереси співробітників у всіх сорерах своєї діяльності. Платформа EmployeeXM дозволяє HR-менеджерам управляти досвідом співробітника на кожному етапі, вчасно реагувати на зниження залученості в роботу, а отже і ефективності.

Компанія Humanyze пропонує платорорму Organizational Health Platform [15] яка забезпечує безперервну аналітику робочого дня співробітника, при цьому захищаючи його конфріденційність. Користувачі отримують оцінку загальної ефективності організації, а також детальний аналіз індикаторів іпоказників за категоріями залученості, продуктивності і адаптованості співробітників. Застосовуючи зазначену платформу в організації, HR-менеджери мають можливість отримувати оцінку ефективності діяльності співробітників в умовах гібридного режиму роботи, що дозволяє оптимізувати співпрацю віддалених команд, покращувати процеси, налаштовуючи команди на успіх і підвищуючи загальну ефективність бізнесу.

Платформа HR-аналітики SplashHR від компанії SplashBI [16] дозволяє управляти людським капіталом і налаштована допомогти HR-менеджерам:

- утримувати найбільш ефективних співробітників;

- наймати і просувати кваліфікованих фрахівців різної національності, статі та віку;

- покращувати процес управління талантами, відстежуючи показники оцінки ефективності;

- оцінювати та підвищувати залученість співробітників;

- визначати області з високою плинністю і планувати зниження ризиків.

Представляє інтерес для сучасного менеджменту персоналу штучний інтелект від компанії Yva.ai [17]. B аспекті оцінки ефективності співробітників він дозволяє оцінювати суб'єктивне сприйняття колегами результативності один одного. Оцінка ефективності в Yva.ai здійснюється через інструментарій розумних опитувань. Співробітники і керівники оцінюють один одного за шкалою від 1 до 5 ( 1 - зовсім не відповідає очікуван- 
ням, 2 - не відповідає очікуванням, 3 - відповідає очікуванням, 4 - перевершує очікування, сильно перевершує очікування). Узагальнені оцінки аналізують керівники і менеджери платорорми, що дає підставу визначити відповідність співробітника очікуванням від його роботи на займаній посаді.

Спираючись на ці результати разом з кількісними методами оцінки персоналу, зокрема найпоширенішим на даний момент в українських компаніях методом КРІ, можна робити комплексні висновки про ефективність співробітників і приймати на їх основі різні кадрові та управлінські рішення, наприклад, підвищення, пониження, ротація, навчання новим методам роботи або інструментам. Високі оцінки ефективності (Performance Evaluation) дозволяють приймати рішення про нагородження співробітників, які цього дійсно заслуговують, грамотно делегувати завдання і наділяти повноваженнями, формувати по-справжньому ефективні команди, у тому числі крос-функціональні.

За даними дослідження $\mathrm{HCl}$ (Human Capital Index) [18], у 72\% компаній індивідуальні результати діяльності оцінюються раз на рік. Таким чином, традиційна система постановки цілей і річної оцінки досягнень зосереджена на минулих результатах, а не на поточній та майбутній ефективності співробітника, тому значимість оцінок і зворотного зв' язку для співробітників знижується, що не дозволяє коригувати їх поведінку в процесі виконання робочих завдань. У зв'язку з цим в управлінні ефективністю персоналу більшість компаній переходить на безперервний процес постановки цілей, оцінювання та зворотного зв'язку.

Оскільки в сучасному мінливому середовищі перегляд цілей і розвиток співробітника відбуваються безперервно, автори вважають, що процеси планування не має сенсу прив'язувати до періоду регулярної оцінки.

Зростання швидкості змін призводить до скорочення періоду регулярної оцінки, тобто якщо раніше атестація персоналу відбувалася раз на рік, то сьогодні все більше організацій використовують механізм зворотного зв'язку в реальному часі (real time feedback).

Серед великих компаній в автоматизації зворотного зв' язку піонерами були "Deloitte" i "Adobe". 32012 poку компанія "Adobe" відмовилась від щорічного рейтингу ефективності співробітників і зробила ставку на безперервний зворотний зв'язок, було впроваджено систему Check-in для розробки і коригування в процесі зворотного зв'язку цільових показників діяльності співробітників, а також створено "центр навчання фрідбек". У результаті на 30\% знизилась кількість звільнень за власним бажанням, підвищились залученість персоналу в робочі процеси і мотивація, керівники і співробітники стали відчувати себе комфортніше, а завдяки збільшенню залученості в роботу зросла ефективність. Ще один позитивний наслідок - люди, які регулярно дають зворотний зв'язок, частіше стають успішними лідерами [19].

Відзначимо, що головний сенс оцінки персоналу полягає не в тому, щоб оцінити. Подібно до того, як загальна міцність ланцюга дорівнює міцності найслабшої ланки, так і в групі - і це особливо актуально для виробничих команд - загальна ефективність зводиться до ефективності найслабкішого з учасників ланцюжка рішень. Це означає, що навчання і розвиток співробіт- ників за результатами оцінки $є$ найважливішим етапом на шляху до успішності як окремих співробітників, так і виробничих команд і компанії в цілому. Оцінка персоналу дозволяє більш точно підбирати і розвивати співробітників під завдання, актуальні для бізнесу, а також знижувати витрати, пов'язані з помилками при прийнятті кадрових рішень.

Але, щоб на виході отримати робочу систему оцінки ефективності персоналу, на старті потрібно обов'язково опрацювати цілі і конкретні завдання. На основі цього необхідно обрати відповідні критерії оцінки, оптимальні методи і інструменти. Застосування навіть частини розглянутого авторами інструментарію оцінки забезпечить керівників і HR-фахівців об'єктивною інформацією про досягнення або помилки в роботі персоналу і дозволить прийняти кадрові рішення, які грунтуються не на емоціях, а на всебічному індивідуальному аналізі співробітника як особистості та його професійного внеску в розвиток компанії.

\section{ВИСНОВКИ}

Отже, проведене дослідження дозволяє зробити висновок, що оцінка персоналу стає більш масовою практикою, в тому числі завдяки розвитку технологій HR-аналітики. Сучасні методи оцінки персоналу відкривають нові можливості для компаній, які працюють над вдосконаленням кадрового апарату. Методи відрізняються широтою, методологічною базою, а також використанням в процесі оцінки комп'ютерних технологій. У компаніях спостерігається природна інтеграція інструментів оцінювання і даних, що забезпечує послідовність і обгрунтованість подальших кадрових рішень на всіх етапах життєвого циклу співробітника в компанії. Виходячи з цього, навчитися вбудовувати оцінку в життєвий цикл співробітника в компанії, обирати найбільш актуальні інструменти і методи оцінки, пов'язувати оцінку 3 ключовими процесами управління персоналом і бізнеспроцесами - одна з головних задач менеджера з персоналу в умовах розвитку гібридних форм роботи і розгалуженості виробничих команд.

\section{Література:}

1. Pasinovych I., \& Starko I. Продуктивність праці: підходи до оцінювання в світлі сучасних глобальних викликів. Вісник Харківського національного університету імені В.Н. Каразіна серія "Економічна". 2020. (98), C. 6-17. DOI: https://doi.org/10.26565/2311-23792020-98-01

2. Крушельницька О.В., Мельничук Д.П. Управління персоналом: навч. посіб. Київ: Кондор, 2003. 296 с.

3. Цимбалюк С.О., Білик О.М. Оцінювання персоналу: навч.посіб. Київ: КНЕУ, 2021.311 с.

4. Малтиз В.В. Оцінка персоналу: сучасні методи та інструменти її проведення. Економіка та суспільство. 2018. № 19. C. 484-489. DOI: https://doi.org/ 10.32782/2524-0072/2018-19-73

5. Кибанов А.Я. Управление персоналом организации: учебник. Москва: ИНФРА-М, 2010.695 с.

6. Апенько С.Н. Оценка персонала: Эволюция подходов и технологии их использования: монография / Под. ред. В.С. Половинко. Москва: Информ-Знание, 2004. 300 c. 
7. Барометр ринку праці України: головні тенденції 2021 року URL: https://eba.com.ua/barometr-rynkupratsi-ukrayiny-golovni-tendentsiyi-2021-roku /

8. Бей Г.В., Середа Г.В., Трансформація HR-технологій під впливом цифровізації бізнес-процесів. Економіка і організація управління. 2019. № 2 (34). C. 93-101. DOI: https://jeou.donnu.edu.ua/article/ view $/ 7355$

9. Как организовать оценку персонала URL: https: / /vip.1kadry.ru /\#/document/16/44991/bssPhr45/ ?of=copy-78ff0da5ba

10. Серьогін С.М., Бородін Є.І., Комарова К.В., Липовська Н.А., Тарасенко Т.М. Управління персоналом в органах публічної влади: навч. посіб. Дніпро: ДРІДУ НАДУ, 2019. 200 с.

11. Lamoureux K. (2008). High potential versus high performance: what is the real difference? URL: http:// www.bersin.com/Practice/Detail.aspx?id=7396

12. Безручко П. Практики регулярного менеджмента. Москва: "Альпина Диджитал", 2019. 222 с.

13. Jaques E. Requisite Organization: A Total System for Effective Managerial Organization and Managerial Leadership for the 21st Century. Florida, USA: Cason Hall \& Co Pub, 2006. 334 p.

14. Новые способы привлечения, развития и удержания ценных кадров. URL: https://www.qualtrics.com/ru/kadrovye/

15. Humanyze Organizational Health Platform ${ }^{\mathrm{TM}}$ Science-backed analytics to inform and improve decisionmaking with speed and certainty. URL: https://humanyze.com/solutions/https://humanyze.com/solutions /

16. People insights for human resources business executives\&managers. URL: https://splashbi.com /

17. Что такое Yva.ai URL: https://www.yva.ai/ru/ about-us

18. Human Capital in the Time of COVID-19 UPDATE 2020 / 2021 International Bank for Reconstruction and Development / The World Bank 1818 H Street NW, Washington, DC 20433. URL: https://www.worldbank.org/ en/publication/human-capital\#Index

19. Как дать обратную связь сотруднику по результатам оценки его работы? URL: https://www.mirapolis.ru/blog/kak-dat-obratnuyu-svyaz-sotrudniku-porezultatam-otsenki-ego-raboty /

References:

1. Pasinovych, I. and Starko, I. (2020), "Labour productivity: approaches to evaluation in the light of modern global challenges", Visnyk Kharkivs'koho natsional'noho universytetu imeni V. N. Karazina seriia "Ekonomichna", vol. (98), pp. 6-17. DOl: https://doi.org/ 10.26565/2311-2379-2020-98-01

2. Krushel'nyts'ka, O.V. and Mel'nychuk, D.P. (2003), Upravlinnia personalom [Personnel management], Kondor, Kyiv, Ukraine.

3. Tsymbaliuk, S.O. and Bilyk, O.M. (2021), Otsiniuvannia personalu [Staff evaluation], KNEU, Kyiv, Ukraine.

4. Maltyz, V.V. (2018), "Personnel evaluation: modern methods and tools for its implementation", Ekonomika ta suspil'stvo, vol. 19, pp. 484-489. DOI: https://doi.org/ 10.32782/2524-0072/2018-19-73
5. Kybanov, A.Ya. (2010), Upravlenye personalom orhanyzatsyy [Personnel management of the organization], YNFRA-M, Moscow, Russia.

6. Apen'ko, S.N. (2004), Otsenka personala: Evoliutsyia podkhodov y tekhnolohyy ykh yspol'zovanyia [Personnel assessment: Evolution of approaches and technology of their use], Ynform-Znanye, Moscow, Russia.

7. EBA (2021), "Barometer of the labor market of Ukraine: the main trends of 2021", available at: https:// eba.com.ua/barometr-rynku-pratsi-ukrayiny-golovnitendentsiyi-2021-roku / (Accessed 25 Oct 2021).

8. Bej, H.V. and Sereda, H.V. (2019), "HR-technologies transformation influenced by digitalization of business processes", Ekonomika i orhanizatsiia upravlinnia, vol. 2 (34), pp. 93-101, available at: https://jeou.donnu.edu.ua/article/view /7355 (Accessed 25 Oct 2021).

9. Krasnova, N. (2021), "How to organize staff assessment", available at: https://vip.1kadry.ru/\#/document $/ 16 / 44991 /$ bssPhr45/? of =copy-78ff0da5ba (Accessed 25 Oct 2021).

10. Ser'ohin, S.M. Borodin, Ye.I. Komarova, K.V. Lypovs'ka, N.A. and Tarasenko, T.M. (2019), Upravlinnia personalom v orhanakh publichnoi vlady [Personnel management in public authorities], DRIDU NADU, Dnipro, Ukraine.

11. Lamoureux, K. (2008), "High potential versus high performance: what is the real difference?", available at: http://www.bersin.com/Practice/Detail.aspx?id=7396 (Accessed 25 Oct 2021).

12. Bezruchko, P. (2019), Praktyky rehuliarnoho menedzhmenta [Practices of regular management], Al'pyna Dydzhytal, Moscow, Russia.

13. Jaques, E. (2006), Requisite Organization: A Total System for Effective Managerial Organization and Managerial Leadership for the 21st Century, Cason Hall \& Co Pub,Florida, U.S.A.

14. Qualtrics (2021), "New ways to attract, develop and retain valuable people", available at: https:// www.qualtrics.com/ru/kadrovye/ (Accessed 25 Oct 2021).

15. Humanyze Organizational Health Platform ${ }^{\mathrm{TM}}$ (2021), "Science-backed analytics to inform and improve decisionmaking with speed and certainty", available at: https:// humanyze.com / solutions / https://humanyze.com / solutions / (Accessed 25 Oct 2021).

16. Splash Business Intelligence Inc. (2021), "People insights for human resources business executives\&managers", available at: https://splashbi.com / (Accessed 25 Oct 2021).

17. Yva.ai (2021), "What is Yva.ai", available at: https://www.yva.ai/ru/about-us (Accessed 25 Oct 2021).

18. International Bank for Reconstruction and Development / The World Bank (2021), "Human Capital in the Time of COVID-19 UPDATE 2020", available at: https:// www.worldbank.org/en/publication/human-capital\#Index (Accessed 25 Oct 2021).

19. Mirapolis (2021), "How to give feedback to an employee on the results of his performance assessment?", available at: https://www.mirapolis.ru/blog/kak-datobratnuyu-svyaz-sotrudniku-po-rezultatam-otsenki-egoraboty/(Accessed 25 Oct 2021).

Стаття надійшла до редакиї 27.10.2021 p. 